\title{
Theorizing Pentecostal Experiences Among Church of God (Cleveland, TN) Adolescents
}

\author{
Christopher Fraley
}

\begin{abstract}
This article describes and theorizes the liturgical contexts in which adolescents have Pentecostal experiences such as "speaking in tongues" and being "slain in the Spirit." It is based on ethnographic research done at a Pentecostal church affiliated with the Church of God (Cleveland, TN). I begin by offering a snapshot of modern Pentecostalism in order to demonstrate the framework that informed the context of the current study. Then I describe six factors of the liturgy that facilitate Pentecostal experience in adolescents: the language of encounter with God, the use of music to build emotional intensity, the prominent role of the body, the participatory nature of worship, the call for salvation, and the alter call as culmination of the liturgy. My analysis reveals that adolescents are more likely to have positive experiences if they have been educated in a Christian environment, had a prayer partner, have experienced a sense of distance from God, have accepted a biblicist approach to Scripture, and have a common bodily experience. I argue that Pentecostal experiences are ultimately beneficial and that a thorough analysis of their underlying factors is essential towards the construction of healthier forms of religious experience.
\end{abstract}

\section{Introduction}

In the century following the Azusa Street Revival, the phenomenon of Pentecostalism has taken the world by storm. ' Its rapid growth has made it the world's fastest growing religious movement (Alexander 2011). Despite its growing popularity, however, there is still much left unknown about this movement which has only begun to attract the attention of more detailed study in recent decades. In particular, attention given to adolescent experiences of Pentecostalism in scholarly literature is very limited. Due to this lack of scholarly attention, and fueled by my own personal experiences of growing up within Pentecostalism, I set out to study adolescent experiences of Pentecostalism. What emerged from the data was the centrality of spiritual experience for Pentecostals which caused me to examine the factors leading to distinctive Pentecostal experiences being transmitted. Thus, through my fieldwork I was able to uncover pertinent themes prevalent within Pentecostalism that uphold its ritual framework and create an environment where experiences of the divine become commonplace.

Pentecostals, despite their emphasis on spontaneity, in fact employ the use of strongly ritualistic elements to centralize encounter with the divine at the heart of the movement. They portray a radical intimacy with the divine absent from many theological traditions and as such represent a unique phenomenon in the face of modern religion. Pentecostal emphasis on divine encounter serves as the focal point of the movement and is the lens through which all other ethnographic data needs to be interpreted. One cannot begin to understand the intricacies of Pentecostalism without first understanding the strong impulse towards divine encounter permeating the movement. With this in mind I set out to explain the occurrences of Pentecostal

\footnotetext{
${ }^{1}$ The Azusa Street Revival, beginning in the spring of 1906 and continuing to 1909, served as a catalyst for the worldwide Pentecostal movement. It occurred in a former African Methodist Episcopal church building located at 312 Azusa Street in Los Angeles, California. The primary leader was the evangelist William J Seymour, who came to Los Angeles from Mississippi to preach the apostolic faith, a teaching that combined the baptism of the Holy Spirit with speaking in tongues, such as was experienced in Jerusalem on the Day of Pentecost, as recorded in Acts 2. It was notable because of the racially integrated nature of its worship services which attracted the attention of local media outlets. The event became a launching pad for many Pentecostal missionaries.
} 
spiritual experiences amongst the Pentecostal adolescents whom I studied.

In what follows I will present a survey of my research on Pentecostal adolescent spiritual experiences. I will begin by giving a very brief introduction to Pentecostalism in order to provide an overview of the defining characteristics of the movement which inform the specific cultural context that I observed. I will then describe the context of my fieldwork and give a description of the methodology I employed before presenting specific data points in regards to the spiritual experiences of my informants. After establishing the context of my research and presenting the data, the remainder of the article will provide a thorough analysis of the data and articulate a compelling explanation for the spiritual experiences of the adolescents I observed that avoids simplistic reductionism and remains sympathetic to the claims of my informants.

I will first highlight six themes which form the foundations of the framework by which Pentecostal experiences are able to occur. I will then describe the differences in liturgical contexts that caused the adolescents observed to only have significant Pentecostal experiences in youth-specific settings and not during the primary liturgy of the local church. Lastly, I will present five themes derived from the informal interviews with the informants who experienced significant Pentecostal encounters as a way to more fully describe the psychological and social factors undergirding the Pentecostal experiences that occurred. I will argue that there are clear patterns of cultural construction surrounding such experiences that can be observed to predict those who will likely have significant Pentecostal experiences. At the same time, however, I will assert the validity of these experiences and go as far as to argue that they are beneficial to the psychological and social development of adolescents when properly understood and integrated into one's life experience. One needs to understand the construction of these experiences so that traditions that encourage their occurrence can move away from unhealthy elements surrounding their construction and present a paradigm that encourages the psychological health of their participants. ${ }^{2}$

\section{A Snapshot of Pentecostalism}

Before proceeding it is important to establish a basic understanding of the development and distinctives of the Pentecostal movement. Pentecostalism finds its roots in the Holiness Movement of the 19th century and its notion of sanctification that came to be interpreted as a distinct event known as Spirit Baptism. Believers would speak in other tongues with accompanying signs as was the case at the Azusa Street Revival in Los Angeles at the turn of the 20th century (Synan 1997). From the beginning of the revival, Pentecostalism quickly began to spread across the globe (Robbins 2004, 121). Missionaries were sent out to evangelize the world under the power of the Holy Spirit (Synan 1997, 133) with the fourfold pattern of Pentecostal theology: Jesus Saves, Jesus Heals, Jesus Baptizes with the Holy Spirit, Jesus is Coming again (Dayton 1987, 19-23). Pentecostalism is a conversionist religion in which the baptism of the Holy Spirit serves as the unveiling of a new way of being in the world (Johns 2010, 92, 95). Since its inception it has become "the most dynamic and fastest growing sector of Protestant Christianity worldwide" (Cassanova 2001, $435)$ with two-thirds of its adherents living outside of the Western world (Barret \& Johnson 2002, 284).

The average Pentecostal uses a common-sense approach to interpreting scripture, rarely relying on interpretive tools such as allegory, and believing that the Holy Spirit will illuminate scriptures to enable interpreters to properly understand it (Stephenson 2013, 16-20). Drawing on the account of Pentecost found in the book of Acts in the Christian New Testament, Pentecostals developed the doctrine of Spirit Baptism as a distinct experience subsequent to one's conversion in which the individual will speak in other tongues as a sign of the infilling of the Spirit who is given to empower and equip believers for Christian life and service (see Horton 2004, 47-94). This emphasis has caused Pentecostals to give priority to the altar experience where leaders will commonly pray and lay hands on those earnestly seeking God for the experience of Spirit Baptism as evidenced by speaking in tongues (Tomberlin 2010). The prominence of glossolalia, better known as 'speaking in tongues,' in this tradition has produced a sort of Pentecostal elitism (Alexander 2009, 47) due to the cathartic dimensions of tongue talking which functions as a protest for those marginalized (Smith 2006, 93). Pentecostals historically have not been well educated, so they have relied on the sign of tongues as validation for the experience and perception of God that is espoused by the movement (Alexander 2009, 47).

With an emphasis on spontaneity and authenticity, Pentecostals condemn ritual as too routine and even unspiritual (Robbins 2011, 50), however, despite

\footnotetext{
${ }^{2}$ What follows is a reworking of original research done for my master's thesis. For a more detailed treatment of the Pentecostal experience of adolescents, including various trajectories suggested by the findings of my research, see "The Spirit Poured Out on All Flesh: The Construction of Pentecostal Experiences Among Adolescents and the Inspiration to Reimagine Ecclesial Practices" (Fraley 2020).
} 
emphasizing the leading of the Spirit, "Pentecostals do in fact engage in rituals, though they often call them by other names: 'worship services,' 'Spiritual practices,' and 'Pentecostal distinctives" (Albrecht 1999, 21-22). Robbins sees the prominence of Pentecostal ritual as the underlying reason for its global spread and institution building capacity (2011). The anti-ritualism that Pentecostals participate in is itself ritualized (Pfeil 2011). For Pentecostals, "the entire ritual field and the drama that emerges within the ritual matrix is aimed toward an encounter. Pentecostals speak of "meeting God" (Albrecht 1992, 110-111). In the Pentecostal tradition, the ritualizing of divine encounter teaches people how to live and behave as Christians rather than structured verbal catechesis (Albrecht 1999, 205).

In constructing the ritual field, Pentecostals use sounds, especially music, which functions as an auditory icon (Albrecht 1992, 111-112). Pentecostal music is appealing because it dramatizes and intensifies feelings, and with the prominence of call-and-response patterns, it elicits the full participation of those present (Alexander 2009, 31, 36). The presence of music is a fundamental aspect of the Pentecostal ritual encounter. Singing stimulates emotion through lyrics, loud, emotive tones and outwards expressions of praise and joy (Wellman et al. 2014). Certain bodily manifestations such as goosebumps are produced by the spike in dopamine naturally occurring when someone is listening to pleasing music (Blood and Zatorri 2001; Salimpoor et al. 2011). The emotional energy produced during the Pentecostal worship experience is given a spiritual meaning through specialized vocabulary (Inbody 2015, 340) which is learned over time from spiritual experts (Luhrman 2012, 111).

Also, the presence of fellow worshippers engaging their bodies in an act of worship becomes a visual icon to those present which expands the ritual field (Albrecht 1992, 112-113). For Pentecostals the body becomes a site where the divine presence can be experienced as evidenced by the prevalence of glossolalia and the experience of being 'slain in the Spirit' (Singleton 2011). Pentecostals share a set of bodily practices such as arms lifted in praise, hands laid on in healing, tongues speaking in prayer, and voices lifted in song (Robbins 2011, 56). Further, "all church members are qualified to initiate and participate in ritual performances. The clergy has no monopoly on ritual. Everyone participates, and whomever the Spirit moves can initiate rituals in most settings. There is no need to have formal training or possess church office (Robbins 2011, 56).” Believing God is intimately involved in the lives of his faithful allows ritual to infuse all domains of social interaction (Csordas 1997, 109).

\section{Context and Methods}

Since I have given a brief overview of the framework which informs the practices of the Pentecostal church I observed, I now turn to describe the specific context of my research and the methods I employed to gather my data. My fieldwork took place at a Pentecostal church that was a part of the classical Pentecostal denomination, the Church of God (Cleveland, TN). The site was in suburban New Jersey in an upper-middle class area with primarily Caucasian residents. While situated in a primarily Caucasian community, the church itself was very diverse ethnically and socially. There were approximately 600 members of the church, however, on any given Sunday there would be approximately 350 people present. I was on staff at the church during the time of my fieldwork, which took place over the course of a year, and had been at the church for two years before starting fieldwork. I worked as the Student Ministries Pastor at the church and oversaw all the discipleship programs from nursery to college age in the church. Although I administrated programs for all these age groups, I was most involved with the church's youth group which was comprised of students from grade six to grade twelve. As such I was responsible for facilitating the weekly youth group gathering and biweekly youth service, also organizing social opportunities for the youth.

As a result of being a staff member, I had a great deal of familiarity with the members of the congregation, particularly the youth, before starting formal fieldwork. This gave me a distinct advantage since I did not have to work hard to build trust with my informants. This familiarity allowed me to retrieve data that I likely would not have been able to uncover if I had no preexisting relationships with the subjects of my study. Instead of having to spend time building relationships and cultivating trust, I was able to focus my attention on participant observation which gave me the ability to fully capture the story I saw unfolding. In addition to participant observation, I conducted semiformal interviews with various youth group members to compile my data. The primary criterion I used to determine whom I would select for an interview was if that individual had experienced a significant Pentecostal encounter during the period of time which I was on staff at the church, however, I also interviewed several students who did not have such experiences.

The focus of my study was on adolescents and their spiritual experience, however, in order to do that it was necessary to develop an understanding of the broader ritual framework of Pentecostalism which necessitated that I observe the congregation as a whole to note the underlying patterns and practices of the church. This was done during the weekly worship gatherings occurring on Sundays and Wednesdays. The primary 
liturgy occurred on Sundays at 9:00 and 11:00 AM and I would be present for the duration of both services which were more or less identical in content. In addition to Sunday services, there was a weekly Wednesday chapel service that occurred at 12:00 PM which I attended as well.

The majority of my time was spent with the youth group and I observed them in a variety of settings. At the church there were approximately 50 students connected to the youth ministry, however, the number that were actively engaged beyond participation in Sunday services was about half of that. Every Wednesday night we would hold youth group and about 12 to 15 students would be in attendance. The meeting was for one hour and was loosely structured to include a time to hang out around food and drinks, a group game, and a devotional time. The students who attended this meeting were the committed students who took their faith more seriously than the average youth in the church. As I led this group, it gave me time to get to know these students on a deeper level and several of the students became the primary informants for my study. As their teacher, I was able to learn special insights from their questions and comments which helped me to understand their experience. I oversaw a biweekly youth service held on Sunday mornings where youth played an active role in the construction of the liturgy. I would offer the sermon most of the time, however, after I was done I would break the youth into small groups of four to six people to go over the content of the sermon. This gave me the opportunity to hear the youth actively wrestle with the content of their faith in a setting without parental influence to shape the course of their conversations.

There were two sites where I spent an extended period of time with the students apart from the local church. The first was at a campground in New York for the annual denominational summer camp and the second was at the annual winter retreat held at a convention center in upstate New York. The youth camp was for a period of five days with students from other churches present. In this setting I was able to observe the youth interacting with peers and taking part in spiritual events that were specifically targeted towards them without any parents or family members there to influence them. The same goes for the winter retreat which took place over three days. Each of these settings was specifically designed to engage youth so I was able to observe the similarities and differences between these targeted settings and the local church context. It is important to note that it was in these settings where I observed students having Pentecostal experiences and that no student had such an experience while at the local church.

\section{Presenting the Data}

Having briefly described the context and methodology I employed during my research, I turn to present the data pertaining to adolescent Pentecostal experiences that I retrieved throughout the fieldwork. Although no students had significant Pentecostal encounters at the local church, 12 different students had experiences common within Pentecostalism while attending Youth Camp and Winterfest. This is out of a combined total of approximately 25 students who were present at either of the two settings. Eight of the students who had these experiences were educated in a Christian environment and two of the remaining four had parents who were highly involved in the local church. Only two of the students who had Pentecostal experiences were educated in public school and had parents not heavily involved in the church. Further, there was no racial distinction between those who had experiences. I have chosen to use the umbrella term of "Pentecostal Experiences" to be more inclusive of experiences that do not necessarily meet the defining criteria of Pentecostal distinctives such as "baptism in the Holy Spirit" or being "slain in the Spirit," but which were still deeply impactful experiences where students perceived that they had encountered God. ${ }^{3}$ For my purposes here, Pentecostal experience refers to experiences in which the individual perceives that they have encountered God bodily, as this perception of a direct personal encounter with God is a defining theme within Pentecostalism.

First in regards to the baptism of the Holy Spirit, three different students experienced this phenomenon. Within Pentecostalism there is some debate as to the exact definition of baptism in the Holy Spirit, however, the church where the fieldwork took place adhered to the interpretation that baptism in the Spirit is signified when an individual speaks in tongues. If tongues are not present, although the experience may still be

\footnotetext{
${ }^{3}$ I distinguish between three categories throughout this article. First, 'baptism in the Spirit' refers to an event in which an individual speaks in other tongues that finds expression as a prayer language not resembling any sort of formal linguistic system. The individual remains conscious during this event, however, it is reported that there is a feeling of passivity when the phrases and syllables are being uttered. This differs from the experience of being 'slain in the Spirit' which occurs when an individual literally falls to the ground after receiving prayer and enters into a trance like state where they are only partially conscious of the events that occur around them. Lastly, the general term of 'Pentecostal experience' refers to experiences where an individual will have certain bodily manifestations and sensations which often accompany being Baptized in the Spirit or being Slain in the Spirit but that do not contain the more definable features of those experiences as discussed above.
} 
considered valuable, it is not defined as baptism in the Holy Spirit. All three of the individuals mentioned had the experience of speaking in other tongues during either Youth Camp or Winterfest.

Several characteristics were present in the accounts given by the students who shared the experience of Spirit Baptism. All three students described feelings of warmth and heaviness throughout their bodies during the experience. Each of the students described intense emotional outbursts where they were uncontrollably sobbing. In all three accounts of Spirit Baptism there was a prayer partner who was actively praying over the student while speaking phrases in tongues. Each student described the feeling of being "free" or that a burden had been lifted off of them. When describing the experience of speaking in tongues, each student noted that they felt as if they were not in control of the words they were speaking. One student described it as, "God using my mouth to speak through me.” Each student described being at a sort of crossroads in their walk with God and feeling as if they needed to recommit themselves to God.

In regards to the experiences themselves, there were common features within each type of Pentecostal experience. Students described sensations of warmth and heaviness in their bodies. Further, emotional outbursts, such as uncontrollable crying, were cited by every student except for one as a marker of their experience. And perceptions of being "free" or of a weight being lifted were cited by students who experienced all different types of encounters. But also, 8 of the 12 students indicated that the experiences were hard to describe and 3 described a feeling of certainty that they received from these experiences. Of the 5 students that experienced either Spirit baptism or being slain in the Spirit, a prayer partner remained with each individual throughout their experience. Of the 7 who had general Pentecostal experiences, only 2 cited having a prayer partner with them during the experience.

Of these experiences, being slain in the Spirit bore the most striking differences from the other accounts. While the two students who experienced this phenomenon both described uncontrollable emotional outbursts, sensations of warmth, and feelings of heaviness these things were only present before the actual experience of being slain in the Spirit. After being slain in the Spirit both students described a trance-like state in which they were only semiconscious. One student described the experience as follows:

I had been praying and crying in the altar for a while before the speaker came over to pray for me. As he started to pray for me I began to cry more intensely and as he laid his hand on my shoulder I began to feel heavy. Before I knew what was happening, the speaker took his hand and placed it on my forehead while speaking in tongues, and as he did I felt my whole body go limp and fall backwards to the floor. I don't remember someone catching me because I was already out by the time I started falling. While lying on the ground it is a hard experience to describe. I could hear things going on around me but it was as if I wasn't actually there but was somewhere else. My body felt like it was floating and I didn't even feel the floor underneath me. My mind was just sort of blank. I didn't have any thoughts, I was just lying there very peaceful without being aware of time passing. Eventually I started to gain more awareness of the room and started to feel the ground underneath me again. Eventually the feeling wore off and I felt like normal again.

Both students described feeling different after the experience occurred. They noted feeling care-free and as if a weight had been lifted off of their shoulders which was described by students who had the other types of experiences as well.

\section{Developing an Understanding of Adolescent Pentecostal Experience}

As I turn my attention to analyzing the ethnographic data I will make three moves. First, I will highlight the dominant elements of Pentecostal liturgy that arose from my observations of the various liturgical contexts. This discussion will be profitable inasmuch as it highlights the ritual framework which makes significant Pentecostal experiences possible. Second, I will discuss the prominent differences between the liturgy of the local church and that of the Youth Camp and Winterfest in order to explain the occurrence of adolescent spiritual experiences at the youth-specific settings exclusively. Lastly, I will return to the data retrieved through informal interviews with my informants regarding their spiritual experiences to further emphasize the underlying factors that were at play that created an environment in which significant Pentecostal experiences could occur.

\section{The Dominant Elements of Pentecostal Ritual Framework}

From my observations of the various liturgical contexts observed during my fieldwork I have categorized six dominant themes that comprise a typical Pentecostal liturgy. Although there were significant differences observed between the liturgy of the local church and the youth-specific settings such as Youth Camp and Winterfest, these six themes were prominent in all the settings observed suggesting a 
general framework for the Pentecostal liturgy. The first theme that I observed is the emphasis on "encounter" language throughout the liturgy which is ritually reinforced through prayer and exhortation. By this I mean statements such as, "press in and seek God," "meet with us in a special way," and "show up in a powerful way." Throughout the liturgies such statements were commonplace and were ritually reinforced through prayer. As Albrecht notes, the entire ritual field of the Pentecostal is aimed towards having a divine encounter (1992), and this purpose was clearly evidenced by the language used by those leading the liturgy.

Prayer not only became a way to encounter God but also a way to redirect one's attention towards God throughout the service. The emphasis on prayer developed a mutual focus of attention that served as the first building block of a successful interaction ritual (Collins 2004). It was common to have an organized prayer performed an average of six times throughout the liturgy. Prayer would be used to open the service, to close out the worship time, to bless the offering, to prepare for the sermon, as a means of completing the sermon and offering an altar call, and as the conclusion of service. Constant repetition served as a reminder that individuals were encountering God and as such could be described as the "cultural kindling" (Luhrmann and Cassaniti 2014) of the experiences had within the service. Through these reminders participants became more susceptible to having an encounter as the prayers served as an element that trained individuals to be more disposed to absorptionthe mental capacity common to many spiritual experiences in which an individual gets caught up in ideas or images; it is the capacity to become focused on the mind's object and allow it to increase while ignoring outside distractions (Luhrmann et al 2010).

The second element was the use of music to increase an emotional build-up alongside the role of the worship leader as a "spiritual expert" guiding participants along in their experience. Music is one of the most prominent ritual elements used to construct the ritual field performed through the liturgy (Albrecht 1992, 111-112) and it served to dramatize feelings and elicit the participation of all those present. The act of singing has been found to stimulate emotions (Wellman et al. 2014) and cause certain bodily manifestations as a result (Blood and Zatorri 2001; Salimpoor et al. 2011), which may explain the sensations described by various informants. The worship leader guided individuals in these experiences and helped them to attribute the bodily and emotional sensations which they were experiencing to divine agency, a process known as "metakinesis" (Luhrmann 2004). Also, worship leaders used their own bodies to model for participants how to worship. In effect, they were training individuals to make their body more receptive to a spiritual experience. As Luhrmann notes, if the mind is trained to be open to supernatural experiences, an individual has a propensity for absorption, and if they are "trained" in absorption through the practice of prayer then they will experience an unusual sensory experience given the right set of circumstances (2004).

The third element is the prominent role of the body throughout the worship experience. Pentecostals do not just think about their experiences, they feel them in a visceral way. The body became a place where the individual radically encountered God whether manifested as goosebumps, feelings of warmth or heaviness, bouts of crying, speaking in tongues etc. It is clear that my informants felt these experiences. Further, observing other students having these experiences encouraged their occurrence as worshiping bodies served as a visual icon to encourage the experience in others (Albrecht 1992). Through bodily practices such as kneeling, lying prostrate, crying, etc., the individuals present achieved a high degree of emotional entrainment with one another which, added to the mutual focus of attention developed around the idea of divine encounter, qualified these experiences as successful interaction rituals (Collins 2004).

The body has a central role within the Pentecostal liturgy as emphasis is repeatedly placed on concrete physical experiences. Singleton notes that the Pentecostal emphasis on "outward bodily experiences reflects the consumerist and body-oriented tendencies of advanced capitalistic society" (2011, 386).” Contemporary consumer society places emphasis on activities that are pleasurable to pursue and places the body as the grounds for these activities to occur (Featherstone 1991, 170). With this in mind we can assume the students present were already disposed to seeking pleasurable physical experiences, and Pentecostal experience carries this type of appeal to those who experience it. The religious ecstasy described by my informants clearly qualifies as a pleasurable physical experience, and their descriptions of these experiences were in keeping with other accounts of similar spiritual experiences (Hood and Williamson 2011). All seven students who had Pentecostal experiences at the Youth Camp also had similar experiences at Winterfest. Once they experienced those feelings, there was stirred in them a desire to experience again the type of divine intimacy that they once felt. Understood in another way, it was after feeling the emotional energy generated by these successful interaction rituals that students were encouraged to return for subsequent experiences as the energy itself is a motivating factor for such experiences (Collins 2004). Through feeling God in these bodily manifestations my informants cultivated a sense of 
intimacy with the divine. It was not the propositional statements about their faith, but rather the direct encounter with the divine that confirmed their beliefs for them. God was not some distant entity uninvolved with the day to day lives of my informants like in the moral therapeutic deism described by Denton and Smith (2005); instead God was intimately involved in their lives and could be felt and experienced.

Fourth, there is the participatory nature of the worship service. My informants were not just casual observers of the liturgy but were active participants in the events that were needed in order to make each encounter a success. This became clear through the way worship leaders would exhort members to "press in and seek God" and the way the speaker would highlight their responsibilities through the prayer before the sermon. In this way, the liturgy itself became an avenue for individuals to experience social belonging and love which may have motivated their actions throughout the worship experience. In these liturgies, individuals found a place where they could belong without fear of judgement. All who attended were there for the same purpose, to encounter God, and the things going on in the outside world did not matter during these times. The Pentecostal liturgy is a communal affair where all those present have a role to play in the community experiencing the presence of God. It is only through full participation that God's presence is made manifest in the service. This allows individuals to feel empowered to carry out the ritual through employing their bodies as instruments of praise and worship. They are instruments of the divine as much as they are receptors of the divine and can help others to experience the Spirit through the laying on of hands and praying over individuals in tongues.

The fifth element is the call for salvation offered at the end of the Pentecostal liturgy. The opportunity for conversion or recommitment is essential as it paves the way for the culmination of the Pentecostal worship experience which is the altar call. The call to salvation opens up a liminal space that offers new possibilities for all who may decide to participate in it (Turner 1967). By offering the call to salvation, the minister allows the participants to reflect and take inventory of their lives in order to note things that are necessary to change. If there is any sin in an individual's life that is separating them from God, it must be confessed and dealt with in order for the individual to once again experience the working of the Spirit. Therefore, sin functions as a psychological barrier separating an individual from God, and as such it is necessary for the individual to receive absolution from this sin. In my observations, ministers tended to play on this feeling of separation and would even exaggerate descriptions of such separation by emphasizing the eternal consequences of not being "right with God.” ${ }^{4}$ By placing cosmic significance on an individual's choice towards reconciliation, stakes are raised and an enormous amount of pressure is placed on the individual to "get right with God." Therefore, by confessing and repenting from one's sin a real weight is lifted from the individual which allows them to experience freely the Spirit during the altar time. This transaction fulfills the individual's need for moral affirmation which is one of the six motivating interests that drive human action, but also it confirms the individual's place within the group and thus fulfills his or her need for social belonging (Smith 2015).

Thus, we arrive at the sixth and final theme: the altar call as the culmination and fulfillment of the Pentecostal liturgy. Everything that happens throughout the service is in anticipation of the moment when the altar call is offered. The altar serves as a visual icon representing the place where the divine presence can be experienced and felt, but it also is a place where new possibilities can be encountered. As Pentecostal theologian Daniel Tomberlin states, "God does not need altars, but humans do. Humans need a sacred place to meet God, because humans are creatures of time and space" $(2010,2)$. The altar call becomes the time and place where God can be encountered in a tangible way. Not one of my informants had a Pentecostal experience that was not directly tied to an altar call experience.

Although they may have felt various emotions throughout the worship services, it was specifically during the altar time that these students perceived that they had encountered God. For the students involved there was the anticipation and expectation that something would happen during the altar experience which made them more disposed to having a vivid spiritual experience. As Luhrmann and Morgain argue in their attentional learning theory of spiritual experience (2012), by having such an expectation and paying more attention to the shifts in mind and body individuals increase the likelihood of such experiences happening. Also, the presence of "prayer partners" during the altar call serving as spiritual experts to guide individuals on their way towards an experience with the divine made this time even more productive in terms of spiritual experience. Often times these prayer partners were adults who were respected and admired by the students which may have encouraged them to further seek these experiences in order to receive the affirmation of their role models. There were, however, many instances when the students themselves spontaneously began to pray for one another during these times which deserves some further exploration.

'For a detailed description of these events see the ethnography within my master's thesis (Fraley 2020). 
Through the liminal space opened by the call to salvation, communitas emerges during altar call experiences. Communitas is understood as a temporary state suspending hierarchical relationships and in which participants stand on equal footing under the direction of the ritual leader (Turner 1969). Communitas emerges in the Pentecostal altar call experience inasmuch as there are no existing barriers that prohibit one from experiencing the divine. Instead, all who are willing can come partake and participants devoid of authority prior to the ritual become empowered to guide others through the liminal process. This is evidenced by the way in which students took initiative to pray over one another during these altar call times without any clear direction to do so. Although leaders were still present at the altar, students assumed the mentoring role indicating a subversion of typical hierarchies.

\section{Differences in Context that May Explain Spiritual Experiences}

Thus far I have listed six dominant themes from Pentecostal liturgical contexts. However, as I noted, no students reported having a Pentecostal experience during the regular weekly services at the local church. All students who had these experiences had them at either the Youth Camp or Winterfest, so it is important to examine the different elements that these contexts offered which made these spiritual experiences possible. I will highlight four key differences that I believe contributed to this discrepancy in experience between the various contexts.

The first difference is observed in the structure of the environments. Whereas at the local church, the sanctuary looked like a traditional place of worship, the environments at both Youth Camp and at Winterfest were set up in way designed to build maximum youth engagement. At Youth Camp the setting was small which forced participants to be in close contact with one another, and coupled with the presence of a large sound system, created an environment that felt like being at a concert, something the students there were all familiar with. Winterfest more directly mirrored this concert atmosphere with the elevated stage, fog machines, stage lights, the dark auditorium and powerful sound system. If one were to walk in during the worship set it would be hard to tell the difference from a typical concert other than the content of the music. ${ }^{5}$ These environ- ments would have felt familiar to the students present and as a result may have lowered their defenses.

Second, being removed from their typical context, and thus removed from friends and parents, may have also made the students more disposed to having significant spiritual experiences. Students were "unplugged" from their normal routine and forced into environments where they had to actively engage and reflect on their own spirituality. This was especially prominent at the Youth Camp as there was little to no cell phone service there, so students were left no choice but to engage in the camp activities. ${ }^{6}$ Also, at the Youth Camp all seven of the students present had a significant spiritual experience, whereas only about half the students present at Winterfest had similar experiences. This suggests that the more removed, or "unplugged", individuals are from their normal context, the more likely they are to have a significant spiritual experience. Further, it appears that students associated these removed contexts as places where significant spiritual experiences occurred. Having the idea that significant experiences happened in these locations prior to participating in these contexts disposed students to having such an experience.

A third difference is in the age of those leading the worship service. Whereas at the local church most individuals involved in leading the service were in their forties and fifties, at both the Youth Camp and Winterfest the facilitators were in their twenties and thirties and had a contemporary look. At the local church facilitators wore dresses and suits, but at the Camp and at Winterfest they wore jeans and t-shirts. They looked like the students and thus gave the students a visual icon which they could connect with and emulate. These were not your typical adults; they were young, hip and fresh. As such, these "leaders" garnered the respect and admiration of the students thus serving as role models for how to engage in their own spirituality. The presence of these visual icons may have made students feel as if they were given license to participate in the liturgy in a greater way than in the local church context where the youth subculture did not find any noticeable expression in the liturgy.

Fourth, the method of delivery between the local church and the youth contexts was drastically different. At the Summer Camp and Winterfest, the music played was contemporary and was highly engaging whereas the music at the local church was more in line with the tastes of their parents. Also, various cultural mediums were used to convey theological themes and to build

\footnotetext{
${ }^{5}$ For a discussion of how Christian environments mimic secular environments see "Creating an Idyllic World for Children’s Spiritual Formation” by Karen-Marie Yust (2006).

${ }^{6}$ For a more detailed discussion of the unique features of Christian youth camps see "The Fundamental Characteristics and Unique Outcomes of Christian Summer Camp Experiences” by Jacob Sorenson (2018).
} 
engagement before the services such as dances, skits and spoken word performances. Again, those performing these aspects of the service were young and relatable for the students present. Also, the sermons offered lively illustrations and used examples common to youth subculture with which the students could connect. Even more, the use of props and acting out scenes from the scriptures made the sermon content come alive for the students. Everything about the delivery of the content was catered to their specific needs and as a result it elicited favorable responses from the students present.

\section{Interpreting Data from the Informants}

Having discussed the main themes of Pentecostal liturgies and the differences that arose between the various contexts, I move to interact directly with the data received from my informants through informal interviewing. From the data, there emerges an explicit link between students who were educated in Christian environments and the students who had Pentecostal experiences. Of the 12 who had significant spiritual experiences, 8 were educated in Christian environments. This confirms the hypothesis that a student's school context will determine how important or active their own faith is (Regnerus et al. 2004, 35). Further, 10 of the 12 had parents who were highly involved in the local church and had experienced Pentecostal experiences in their own lives. This confirms the findings of Denton and Smith (2005) that the most religiously involved teens typically have parents that are highly involved, and their experiences and beliefs mirror one another. All the teens observed had experiences common within Pentecostalism which confirms that individuals have experiences typical of their religious tradition (Smith 2003; Luhrmann and Cassaniti 2014).

Second, there emerged a link between the presence of a prayer partner and the occurrence of the more definable Pentecostal experiences of Spirit Baptism and being slain in the Spirit. All 5 of the students that had these types of encounters had a prayer partner who remained with them throughout the duration of their experiences. These prayer partners functioned as spiritual experts (Luhrmann 2012) who were present to guide the students through their experiences. They modeled for them the way to pray and seek God, but even more they encouraged the students to press in and seek God for themselves. They were role models for the students to emulate (Smith 2003; Denton and Smith 2005) whose presence may have encouraged more active participation on the part of the students as they were likely motivated to seek the approval of those praying for them.

A third common theme is feeling distant from God prior to having a significant spiritual experience. With 7 of the 12 articulating this notion it suggests that there is a strong correlation between having a desire to draw close to God and experiencing a type of Pentecostal experience. This confirms that when individuals focus their minds on experiencing the divine they are more disposed to having experiences attributed to divine agency (Luhrmann et al. 2012). In connection with this, there was a fear of not being right with God which motivated several students towards their spiritual experiences. Three students explicitly listed their fear of not being right with God as their reason for seeking such a spiritual experience, with three more hinting at this idea as well. With these underlying fears present, speakers were able to play on those fears and position altar calls in a way that pressured students into making an emotional decision. The students wanted to be in right standing with God and experiencing God in a tangible way served as a signifier that they achieved that goal, thus the absolution felt from the experience is itself a motivating factor.

Fourth, there appeared to be a clear distinction between students who had Pentecostal experiences and those who did not that centered around the way that they viewed scripture. Ten of the students who had Pentecostal experiences adopted the biblicist approach ${ }^{7}$ common to the church which emphasized the Bible's "exclusive authority, infallibility, perspicuity, selfsufficiency, internal consistency, self-evident meaning, and universal applicability" (Smith 2011, viii). The church espoused the notion that the Bible is a handbook for Christian living that could be readily understood by all those who open its pages and as such should be used exclusively to guide one's faith and practice. The issue with this view is that the Bible is not always clear and consistent on theological and ethical matters, which makes its application a daunting task and leads to the pervasive interpretive pluralism seen throughout the various expressions of Christianity (Smith 2011). Students who did not view the scripture this way tended not to have significant Pentecostal experiences as they expressed a fair degree of skepticism that such experiences were legitimate. This is an interesting distinction that warrants further investigation in the future.

The fifth and final theme was the similarity in the descriptions of the Pentecostal experiences my informants had as well as the positive effects these

${ }^{7}$ For a detailed description of this approach to scripture see Christian Smith's The Bible Made Impossible: Why Biblicism is Not a Truly Evangelical Reading of Scripture (2011). 
experiences had on them. There was a high degree of consistency in descriptions of the physical sensations experienced by my informants suggesting the universality of the nature of these experiences. As mentioned previously, the descriptions of these sensations bore marked similarity to a previous phenomenological study of Pentecostal experience (Hood and Williamson 2011). There is a consistency in experience that emerges in those who have Pentecostal encounters regardless of the underlying motivating factors. Further, there is existing evidence which supports the experience of my informants. My informants described the sensation of not being in control of the words they were speaking when they experienced Spirit Baptism and the overall ineffable nature of these spiritual experiences. One study found that those who engaged in glossolalia exhibited greater activation of the right cerebral hemisphere processes, which has been historically more associated with mystical states than during a discursive reading activity (Mueller and Philipchalk 2000). This study supports the notion that those engaging in the practice of glossolalia through the experience of Spirit Baptism are entering into a mystical state of consciousness. Another study confirmed two hypotheses in regards to brain activity during glossolalia. First during glossolalia there was a decrease in parietal frontal lobe (PFL) activity when compared with singing, as PFL is involved with willful behaviors, and there were no significant decreases in the superior parietal lobe (SPL) when compared with meditation, as the SPL has been shown to deactivate with the experience of a loss or altered state of consciousness (Newberg et al. 2006). Finally, a more recent study indicated that during glossolalic speech the participant entered a stage of brain activity resembling light sleep (Reeves et al. 2014). These findings support the claims of Pentecostal glossolalists who indicate an element of passivity during these experiences.

\section{Conclusion}

In conclusion, my informants clearly underwent concrete physical experiences that were interpreted as significant religious experiences which had an immediate impact on their own mental wellbeing. Although there are clear patterns of cultural construction surrounding these experiences, that should not cause one to simply dismiss the claims of those who have such experiences as invalid without first hearing how these experiences have impacted them on a personal level. The noted difficulty in describing these experiences as well as the feelings of certainty derived from these experiences is in keeping the noetic and ineffable qualities of mystical encounters described by William James (1982) and is also in line with the findings of Hood and Williamson (2011) from their phenomenological study of Spirit Baptism. As I have mentioned, there is existing evidence that supports the mystical and passive dimensions of experiences such as Spirit Baptism and glossolalia. What my informants experienced were clearly mystical encounters that relieved anxiety and tension and caused many of them to describe the feelings of being free or having a weight lifted off of them later. It is my belief that these experiences had an overall positive impact on the students who had them, and in the case of some informants, directly helped them to change undesirable behaviors that they had previously exhibited. In this way I believe that these experiences are valuable and when understood in a healthy way can lead to positive life changes in those who have them.

The beneficial role of religion and religious experiences in the lives of adolescents has long been noted. Adolescents who fall into the "Devoted" and the "Regular" categories suggested by Denton and Smith are more likely to avoid problems typical of adolescence and to achieve positive life outcomes (2005). Evidence has shown that healthy spirituality can increase resilience in adolescents (Esquivel and Kim 2011). Spirituality may facilitate resilience by helping build attachment relationships, by opening access to sources of social support, by guiding conduct and values, and by offering opportunities for personal growth and development (Crawford et al. 2006). Further, religion functions as a meaning system and provides life purpose in the face of highly stressful situations (Park 2007). The religious context promotes a sense of identity that promotes a concern for the social good and as such provides a unique setting for adolescent identity formation (King 2003). Although a sense of purpose can be developed outside of a religious context, many individuals find meaning through religious faith which sustains them through difficult situations (Esquivel and Kim 2011). This sense of meaning found in those with higher religiosity correlates to less of a likelihood of adolescents using substances including alcohol, tobacco and marijuana (Johnson 2008; Sandy et al. 2003).

With this in mind one should avoid the temptation to dismiss these experiences using simplistic reductionism. Instead focus should be shifted towards how knowledge of the construction of such experiences can be employed to create healthier, more sustainable forms of religious experience that can serve to ground the religious identity of adolescents so that they can partake in the positive life outcomes associated with a healthy, vibrant spirituality. In my research there were definitely aspects of the construction of these experiences that bordered on manipulation and had negative psychological effects on the students themselves. Specifically, the role of fear of "not being 
right with God" as a motivating factor needs to be addressed. I have written elsewhere on the inadequacy of the theological paradigm presented within the tradition I observed that portrays God in a way that perpetuates such fear (Fraley 2020). For here, suffice it to say that within Christianity there are various models of God and there is no need for one to subject themselves to an antiquated conception of God that so clearly produces undesirable psychological effects. ${ }^{8}$

Just as from the data one is able to see that a shift needs to be made from older conceptions of God in order to promote psychological health, so too one can also see that the influence of role models in these spiritual experiences needs to be observed and regulated to ensure that undue pressure is not being placed on adolescents to manipulate a certain outcome. This was prevalent during altar call encounters I observed where youth leaders would remain with individuals coaching them throughout the experience. Although I think there is a degree to which this can be beneficial, it becomes problematic when a leader becomes aggressive both physically and verbally in trying to bring about such an experience for adolescents. Youth have respect and admiration for those who serve as their leaders and the power and privilege that comes with a position of leadership should not be leveraged to manipulate a spiritual outcome when a student clearly would not otherwise experience that outcome without added pressure.

Although I have discussed only two aspects of these encounters that need to be reassessed in light of the data, there are other insights that can be capitalized on as well by spiritual leaders willing to introspect on their own practices and behaviors. Therefore, I do not provide explanations of these experiences as a means to dismiss them, rather explanation is provided with the hopes that it can lead to positive changes in patterns and practices. What is clear is that Pentecostal encounters are significant experiences that can have a lasting impact on the psychological and social development of the adolescents who have them. As such they should be seen as a valuable tool to facilitate spiritual growth and development and should be approached critically in order to increase the efficacy of their implementation. Recognizing the impactful nature of these encounters takes seriously the experience of the informants and actively listens in order to learn from their experience.

An approach that takes seriously the claims of the informants is foundational to any truly engaged anthropology. Therefore, we should work to validate the experiences of our informants and listen to what they are telling us so that a trajectory can be set that involves healthy growth and development rather than allowing practices to remain stale and stagnant. In this case in particular, that involves a critical evaluation of certain practices as sketched above which will ultimately lead to a situation where a person can partake in the positive effects of religious experience without being subjected to its negative consequences.

\section{Bibliography}

Albrecht, Daniel E. 1992. Pentecostal Spirituality: Looking Through the Lens of Ritual. Pneuma 14 (2):107-125.

1999. Rites in the Spirit: A Ritual Approach to Pentecostal/Charismatic Spirituality. Sheffield, UK: Sheffield Academic Press.

Alexander, Paul. 2009. Signs and Wonders: Why Pentecostalism is the World's Fastest Growing Faith. San Francisco: Jossey-Bass.

Barret, D. B. and T. M. Johnson. 2002. Global Statistics. In The New International Dictionary of Pentecostal and Charismatic Movements. Van der Mass, Eduard and Stanley M. Burgess, eds. Pp. 283-302. Grand Rapids, MI: Zondervan.

Blood, A. J., and R. J. Zatorre. 2001. Intensely Pleasurable Responses to Music Correlate with Activity in Brain Regions Implicated in Reward and Emotion. Proceedings of the National Academy of Sciences Biological Sciences 98:118-123.

Casanova, Jose. 2001. Religion, the New Millennium, and Globalization. Sociology of Religion 62 (4): 415-441.

Collins, Randall. 2004. Interactions Ritual Chains. Princeton, NJ: Princeton University Press.

Crawford, Emily, Margaret Wright, and Ann S. Masten. 2006. Resilience and Spirituality in Youth. In The Handbook of Spiritual Development in Childhood and Adolescence. Eugene Roehlkepartai, Pamela King, Linda Wagener, and Peter Benson, eds. Pp. 355-370. Thousand Oaks, CA: Sage.

Csordas, Thomas J. 1997. Language, Charisma, and Creativity: The Ritual Life of a Religious Movement. Berkley: University of California Press.

Dayton, Donald W. 1987. Theological Roots of Pentecostalism. Peabody, Mass: Hendrickson Publishers.

\footnotetext{
${ }^{8}$ For examples of how theologians have explored alternate conceptions of God see Sallie McFague's Models of God: Theology for an Ecological, Nuclear Age (1987), as well as Elizabeth's Johnson's She Who Is: The Mystery of God in Feminist Theological Discourse (1992). Both authors present alternative visions of God that deviate from the model of God portrayed in the context of my fieldwork.
} 
Denton, Melissa, Robert Faris, and Christian Smith. 2003. Mapping American Adolescent Subjective Religiosity and Attitudes of Alienation Toward Religion: A Research Report. Sociology of Religion 64 (1):111-133.

Denton, Melissa and Christian Smith. 2005. Soul Searching: The Religious and Spiritual Lives of American Teenagers. New York: Oxford University Press.

Esquivel, Giselle B. and Sangwon Kim. 2011. Adolescent Spirituality and Resilience: Theory, Research and Educational Practices. Psychology in the Schools 48(7): 755-765.

Featherstone, Michael. 1991. The Body in Consumer Society. In The Body: Social Process and Cultural Theory. Michael Featherstone, Michael Hepworth, and Brian Turner, eds. Pp. 170-198, London: Sage.

Fraley, Christopher. 2020. The Spirit Poured Out on All Flesh: The Construction of Pentecostal Experiences Among Adolescents and the Inspiration to Reimagine Ecclesial Practices. Master's Thesis. Eastern University. Wayne, PA.

Hood Jr., Ralph W. and W. Paul Williamson. 2011. Spirit Baptism: A Phenomenological Study of Religious Experience. Mental Health, Religion and Culture 14 (6): 543-559.

Horton, Stanley M. Spirit Baptism: A Pentecostal Perspective. In Perspectives on Spirit Baptism. Chad Owen Brand, ed. Pp. 47-104. Nashville: Broadman \& Holman Publishers.

Inbody, Joel. 2015. Sensing God: Bodily Manifestation and Their Interpretation in Pentecostal Rituals and Everyday Life. Sociology of Religion 76 (3):337-355.

James, William. 1982. The Varieties of Religious Experience. New York: The Penguin Group.

Johns, Cheryl Bridges. 2010. Pentecostal Formation: A Pedagogy among the Oppressed. Eugene, OR: Wipf and Stock Publishers.

Johnson, B.R. 2008. A tale of Two Religious Effects: Evidence for the Protective and Prosocial Impact of Organic Religion. In Authoritative Communities: The Scientific Case for Nurturing the Whole Child. Kathleen K. Kline, ed. Pp. 187-225. New York: Springer.

Johnson, Elizabeth. 1992. She Who Is: The Mystery of God in Feminist Theological Discourse. New York, NY: Crossroad Publishing Company.

King, Pamela Ebstyne. 2003. Religion and Identity: The Role of Ideological, Social and Spiritual Contexts. Applied Developmental Science 2003 7(3):197-204.
Luhrmann, Tanya M. 2004. Metakinesis: How God Becomes Intimate in Contemporary U.S. Christianity. American Anthropologist 106 (3):518-528.

. 2012. When God Talks Back: Understanding the American Evangelical Relationship with God. NY: Vintage Books.

Luhrmann, Tanya and Julia Cassaniti. 2014. The Cultural Kindling of Spiritual Experiences. Current Anthropology $55(10): 333-343$

Luhrmann, Tanya, Howard Nusbaum, and Ronald Thisted. 2010. The Absorption Hypothesis: Learning to Hear God in Evangelical Christianity. American Anthropologist 112 (1):66-78.

Luhrmann, Tanya, Howard Nusbaum, Ronald Thisted, and Rachel Morgain. 2012. Prayer as Inner Sense Cultivation: An Attentional Learning Theory of Spiritual Experience. Ethos 40 (4):359-389.

McFague, Sallie. 1987. Models of God: Theology for an Ecological, Nuclear Age. Minneapolis: Fortress Press.

Mueller, Dieter and Ronald P. Philipchalk. 2000. Glossolalia and Temperature Change in the Right and Left Cerebral Hemispheres. The International.Journal for the Psychology of Religion 10 (3):181-185.

Newberg, Andrew B, Nancy Wintering, Donna Morgan, and Mark Waldman. 2006. The Measurement of Regional Cerebral Blood Flow During Glossolalia: A Preliminary SPECT Study. Psychiatry Research: Neuroimaging Section 148 (1):67-71.

Park, Crystal L. 2007. Religiousness/Spirituality and Health: A Meaning Systems Perspective. Journal of Behavioral Medicine 30:319-328.

Pfeil, Gretchen. 2011. Imperfect Vessels: Emotion and Rituals of Anti-Ritual in American Pentecostal and Charismatic Devotional Life. In Practicing the Faith: The Ritual Life of Pentecostal-Charismatic Christians. Martin Lindhardt, ed. Pp. 49-67. New York: Berghahn Books.

Reeves, Roy R, Samet Hose, and Abuhuziefa Abubakr. 2014. Temporal Lobe Discharges and Glossolalia. Neurocase 20(2):236-240.

Regnerus, Mark D, Christian Smith, and Brad Smith. 2004. Social Context in the Development of Adolescent Religiosity. Applied Developmental Science 8 (1):27-38.

Robbins, Joel. 2004. The Globalization of Pentecostal and Charismatic Christianity. Annual Review of Anthropology 33:117-143. 
2011. The Obvious Aspects of Pentecostalism: Ritual and Pentecostal Globalization. In Practicing the Faith: The Ritual Life of Pentecostal-Charismatic Christians. Martin Lindhardt, ed. Pp. 49-67. New York: Berghahn Books.

Salimpoor, Valorie N., Mitchel Benovoy, Kevin Larcher, Alain Dagher, and Robert J. Zatorre. 2011. Anatomically Distinct Dopamine Release During Anticipation and Experience of Peak Emotion to Music. Nature Neuroscience 14:257-262.

Singleton, Andrew. 2011. The Rise and Fall of the Pentecostals: The Role and Significance of the Body in Pentecostal Spirituality. Scripta Instituti Donneriani Aboensis 23:381-399.

Smith, Christian. 2003. Theorizing Religious Effects Among American Adolescents. Journal for the Scientific Study of Religion 42 (1):17-30.

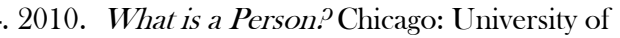
Chicago Press.

2011. The Bible Made Impossible: Why Biblicism is Not a Truly Evangelical Reading of Scripture. Grand Rapids, MI: Brazos Press.

- 2015. To Flourish or Destruct: A Personalist Theory of Human Goods, Motivations, Failure and Evil. Chicago: University of Chicago Press.

Smith, James K.A. 2006. Tongues as 'Resistance Discourse'-A Philosophical Perspective. In Speaking in Tongues: Multi-Disciplinary Perspectives. Mark Cartledge, ed. Pp. 81-110. Eugene, OR: Wipf and Stock Publishers.

Sorensen, Jacob. 2018. The Fundamental Characteristics and Unique Outcomes of Christian Summer Camp Experiences. Journal of Youth Development 13(1-2): 183-200.

Stephenson, Christopher A. 2013. Types of Pentecostal Theology. New York: Oxford University Press.

Synan, Vinson. 1997. The Holiness-Pentecostal Tradition: Charismatic Movements in the Twentieth Century. Grand Rapids: Eerdmans Publishing Company.

Tomberlin, Daniel. 2010. Pentecostal Sacraments: Encountering God at the Alter. Cleveland: Center for Pentecostal Leadership and Care.

Turner, Victor. 1967. Betwixt and Between: The Liminal Period in Rites de Passage. In The Forest of Symbols: Aspects of Ndembu Ritual. Pp. 93-111. Ithica: Cornell University Press.

1969. Liminality and Communitas. In The Ritual Process: Structure and Anti-Structure. Pp. 94-130. New York: Routledge.
Wellman, James K. Jr., Katie E. Cororan, and Kate StocklyMeyerdirk. 2014. “God Is Like A Drug. . .”: Explaining Interaction Ritual Chains in American Megachurches. Sociological Forum 29 (3):650-72.

Wills, Thomas A, Alison M. Yaeger, and James M Sandy. Buffering Effect of Religiosity for Adolescent Substance Abuse. Psychology of Addictive Behaviors 17(1):24-31.

Yust, Karen-Marie. 2006. Creating an Idyllic World for Children's Spiritual Formations. International Journal of Children's Spirituality 11(1):177-188.

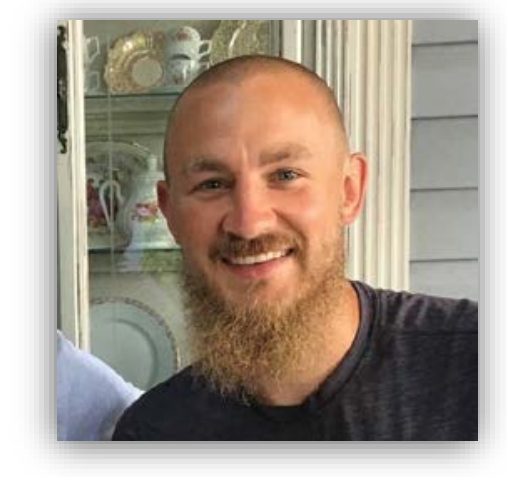

Christopher Fraley is a graduate of Eastern University's Master of Arts in Theological and Cultural Anthropology and holds a Bachelor of Arts in Biblical and Theological Studies from Lee University. He currently works as a Support Coordinator at Neighbours Inc. where he utilizes his ethnographic skills to capture the stories of individuals with intellectual and developmental disabilities in order to help them create a meaningful life where they are engaged in and valued by their local community. He resides in New Jersey with his wife Jessica and their three children, Elijah, Reiyah, and Judah.

Author email: christopher.fraley@eastern.edu 